\title{
Consequences of light limitation for carbon acquisition in three rhodophytes
}

\author{
Janet E. Kübler, John A. Raven \\ Department of Biological Sciences, University of Dundee, Dundee DD1 4HN, United Kingdom
}

\begin{abstract}
We investigated the consequences of growth at limiting photon flux density (PFD) for the uptake of inorganic carbon by 2 species of red seaweed which are able to use $\mathrm{HCO}_{3}{ }^{-}$for photosynthesis [Palmaria palmata (Huds.) Lamour and Laurencia pinnatifida (L.) Kuntze] and one which is dependent on diffusive uptake of bulk $\mathrm{CO}_{2}$ [Lomentaria articulata (Huds.) Lyngb.] We attempted to induce energetic limitation of plants and/or reduce their demand for inorganic carbon by growing them at a low PFD and comparing their carbon use characteristics with those of plants grown at high PFD. There were significant increases in the carbon isotope discrimination (more negative delta values relative to the PDB standard) when the 3 species were grown at 25 relative to $75 \mu \mathrm{mol}$ photons $\mathrm{m}^{-2} \mathrm{~s}^{-1}$. In the 2 species which are able to use bicarbonate, the decreased $\delta^{13} \mathrm{C}$ was associated with lower initial slopes of inorganic carbon uptake curves. Taken together, the changes in $\delta^{13} \mathrm{C}$ and dissolved organic carbon uptake indicated that light-limited $P$. palmata and $L$. pinnatifida were not using low concentrations of inorganic carbon as efficiently as were plants grown at high PFD. This hypothesis was further supported by evidence that light limitation also caused a reduction in C:N ratio and in the \% dry matter made up of carbon in those species. In contrast, growth of L. articulata, which is dependent on diffusive uptake of $\mathrm{CO}_{2}$ for photosynthesis, was inhibited by the higher PFD and there were no significant effects of growth PFD on inorganic carbon uptake efficiency, C:N ratio or \% C in this species.
\end{abstract}

KEY WORDS: Laurencia pinnatifida $\cdot$ Lomentaria articulata $\cdot$ Palmaria palmata $\cdot \mathrm{CO}_{2} \cdot \mathrm{HCO}_{3}{ }^{-} \cdot$ Light limitation - Photosynthesis - Stable carbon isotope ratios

\section{INTRODUCTION}

Understanding the uptake of dissolved inorganic carbon (DIC) by marine macrophytes is more difficult than in the case of terrestrial plants, which have their leaves in the air. All gas exchanges between the media and submerged plants are complicated by the slower diffusion in water, which is not completely offset by the thinner diffusion boundary layers in water under comparable fluid-flow/plant-size combinations, chemical equilibria of inorganic carbon species in large volumes of external solution and the possible biological interaction with these processes (e.g. the production of carbonic anhydrase). Algae which are able to photosynthesize at high rates in seawater have evolved means of using bicarbonate (which makes up about $90 \%$ of the total inorganic carbon pool in seawater at the typical pH of around 8.0) (Bidwell \& MacLachlan 1985. Beer \& Israel 1990, Maberly 1990) thereby raising the inorganic carbon concentration at the site of carboxylation, and hence the photosynthetic rate, above that possible if carbon uptake occurred only via passive diffusion (Maberly et al. 1992, Raven et al. 1993). Any means of increasing the concentration of $\mathrm{CO}_{2}$ in the chloroplasts (where carbon fixation occurs) above the equilibrium concentration achieved by diffusion can be thought of as a carbon concentrating mechanism (CCM). There are, however, species of red algae which are unable to utilize $\mathrm{HCO}_{3}{ }^{-}$as a photosynthetic carbon source (Johnston et al. 1992).

The mechanistic specifics of the CCM have only recently been partially elucidated for some green microalgae (Rotatore et al. 1992, Ramazanov et al. 1993) and remain largely undescribed for rhodophytes and phaeophytes (but see Cook \& Colman 1987, Cook et al. 1988, Smith \& Bidwell 1989). However, the characteristics of carbon use have made it possible to identify algae in which a CCM is or is not operating, as they 
have photosynthetic rates and inorganic carbon affinities which are too great to be supported by diffusive entry of dissolved $\mathrm{CO}_{2}$ alone (Maberly 1990, Maberly et al. 1992). There are indications that the CCM is inducible by carbon limitation in several species of macroalgae (see Surif \& Raven 1990, Levavasseur et al. 1991 and Maberly et al. 1992 for discussion of the degree of suppression of the $\mathrm{CCM}$ ); that is, plants growing in adequate carbon concentrations do not operate the CCM. The strongly facultative nature of the CCM suggests that there is considerable energetic cost to its operation, indeed, strong enough to outweigh the potential benefit of enhanced productivity under conditions where carbon concentration may be temporarily limiting the rate of photosynthesis, for example during light flecks. There have been attempts to determine the quantum cost of operating an active inorganic carbon uptake mechanism. In general there appeared to be a decrease in quantum yield for photosynthesis under conditions where a CCM would be operating (Raven \& Lucas 1985 and references therein, Beardall 1991).

Here, we attempted to make use of this energetic cost to repress/derepress the CCM by manipulating a factor other than the inorganic carbon concentration or the $\mathrm{pH}$. That is, we used a demand side scheme to lower the need for carbon uptake (the photosynthetic rate) by lowering the photon flux density (PFD) at which the plants were grown. We used 3 species of red macrophyte, 2 of which have been previously shown to possess a CCM (Palmaria palmata and Laurencia pinnatifida) and 1 which does not (Lomentaria articulata) (Maberly 1990, Johnston et al. 1992). We were able to compare the photosynthetic characteristics of a given species with its CCM functioning at different levels of efficiency, under the same external carbon concentrations, and also to compare the effect of growth conditions on species which do and do not possess a CCM.

\section{METHODS}

Collection and culture conditions. Palmaria palmata (L.) Kuntze, Laurencia pinnatifida (Huds.) Lamour and Lomentaria articulata (Huds.) Lyngb. were collected from Castle Rocks, St. Andrews, UK $\left(2^{\circ} 7^{\prime} \mathrm{W}, 56^{\circ} 20^{\prime} \mathrm{N}\right)$. Plants were cleaned of any visible epiphytes and grown in the laboratory at $10^{\circ} \mathrm{C}$ in Provasoli enriched seawater media (PES; Provasoli 1968) at either $75 \pm 5$ or $25 \pm 5 \mu \mathrm{mol}$ photons $\mathrm{m}^{-2} \mathrm{~s}^{-1}$ in a $12 \mathrm{~h}: 12 \mathrm{~h}$ light: dark cycle. All cultures were vigorously aerated, which maintained air equilibrium levels of DIC (Kübler unpubl. data). The media were changed every 5 to $6 \mathrm{~d}$, at which time plants were cleaned with paper towels and the biomass density maintained at 1.0 to $1.5 \mathrm{~g} \mathrm{l}^{-1}$.
Growth rates were determined by reweighing 10 blotted, tagged individuals in each culture at each media change and calculating the specific growth rate per day. Plants grown under these conditions were used for all further measurements. The growth experiment was repeated and data from the 2 repetitions were pooled.

Carbon and nitrogen content and carbon stable isotope ratio. Subsamples of each culture were blotted to remove surface water, weighed, dried overnight at $80^{\circ} \mathrm{C}$, reweighed and ground to powder. Subsamples consisted of whole individual plants or, in the case of Lomentaria articulata, 2 or 3 whole individuals. C:N ratios and $\delta^{13} \mathrm{C}$ values (relative to the PDB standard) were determined on $\sim 1 \mathrm{mg}$ of the dried, powdered subsamples in a combined Carlo-Erba elemental analyzer/VG SIRA. II mass spectrophotometer. The $\delta^{13} \mathrm{C}$ value of organic carbon has been previously shown to be a sensitive indicator of the inorganic carbon source for photosynthesis in macroalgae, with plants restricted to $\mathrm{CO}_{2}$ use having values in the range of -35 to $-30 \%$, while those which also use $\mathrm{HCO}_{3}{ }^{-}$have values $>-25 \%$ (Maberly et al. 1992). These different stable carbon isotope signals reflect the discrimination of ribulose-1,5-bisphosphate carboxylase acting on intracellar carbon pools derived from $\mathrm{HCO}_{3}{ }^{-}$and/or dissolved $\mathrm{CO}_{2}$, with the $\mathrm{CO}_{2}$ in seawater being $\sim 10 \%$ o more negative than the $\mathrm{HCO}_{3}^{-}(\mathrm{Mook}$ et al. 1974, O'Leary 1992). Carbon fixation rates per unit tissue nitrogen were calculated according to Surif \& Raven (1990) from the organic nitrogen content and the maximum photosynthetic rate (see below).

Inorganic carbon dose response curves. The response of net photosynthetic rate to inorganic carbon concentration was determined at $10^{\circ} \mathrm{C}$ in a Hansatech $\mathrm{O}_{2}$ electrode. $\mathrm{CO}_{2}$-free seawater was prepared by acidifying Millipore-filtered seawater to $\mathrm{pH} \leq 4.0$ and sparging with $\mathrm{N}_{2}$ for at least $5 \mathrm{~h}$. Tris-base buffer (25 mM) was then added and the $\mathrm{pH}$ adjusted to 8.0 with carbonate-free $\mathrm{NaOH}$ prepared as described in Johnston et al. (1992). An apical section of plant material $(\sim 30 \mathrm{mg})$ was placed in the electrode chamber with $2 \mathrm{ml}$ of $\mathrm{CO}_{2}$-free buffered seawater and $\mathrm{O}_{2}$ exchange measured. $\mathrm{NaHCO}_{3}$ solution was injected and photosynthesis measured over a range of concentrations up to $10.0 \mathrm{mM}$. The initial slopes of DIC response curves were calculated by linear regression over the range of 0.0 to $0.8 \mathrm{mM} \mathrm{HCO}_{3}{ }^{-}$. The slope is taken to indicate how effectively plants use low concentrations of inorganic carbon, as discussed by Johnston et al. (1992). The mean maximum rate of net photosynthesis $\left(P_{\max }\right)$ was calculated as the mean highest rate of oxygen evolution recorded in the course of each response curve.

Chlorophyll a content was subsequently determined for each apex. Chlorophyll a was extracted by sequen- 
Table 1. Palmaria palmata, Laurencia pinnatifida and Lomentaria articulata. Characteristics of seaweeds grown at $75 \pm 5 \mu m o l$ photons $\mathrm{m}^{-2} \mathrm{~s}^{-1}$ (high PFD) or $25 \pm 5 \mu \mathrm{mol}$ photons $\mathrm{m}^{-2} \mathrm{~s}^{-1}$ (low PFD). Values are given as mean (SE) for $\mathrm{n}=5$ to 10

\begin{tabular}{|lcccccc|}
\hline & \multicolumn{2}{c}{ P. palmata } & \multicolumn{2}{c}{ L. pinnatifida } & \multicolumn{2}{c}{ L. articulata } \\
& High PFD & Low PFD & High PFD & Low PFD & High PFD & Low PFD \\
\hline Growth (\% d $\left.{ }^{-1}\right)$ & $7.0(1.2)$ & $3.7(0.8)$ & $3.0(0.5)$ & $1.2(0.2)$ & $2.0(1.1)$ & $3.2(1.0)$ \\
$\%$ Dry biomass & $18.1(0.7)$ & $16.5(0.5)$ & $14.2(0.8)$ & $12.9(0.4)$ & $17.6(0.3)$ & $17.1(0.5)$ \\
$\% \mathrm{C}$ (of dry wt) & $34.7(0.7)$ & $30.6(0.6)$ & $32.4(0.6)$ & $30.1(0.4)$ & $29.9(0.6)$ & $30.3(0.5)$ \\
$\% \mathrm{~N}$ (of dry wt) & $3.06(0.63)$ & $3.82(0.04)$ & $3.21(0.04)$ & $3.34(0.14)$ & $3.51(0.08)$ & $3.75(0.09)$ \\
Chlorophyll a $\left(\mathrm{\mu g} \mathrm{g}^{-1}\right)$ & $0.12(0.02)$ & $0.19(0.01)$ & $0.17(0.04)$ & $0.15(0.01)$ & $0.17(0.20)$ & $0.19(0.2)$ \\
$P_{\max }\left(\mu m o l \mathrm{O}_{2} \mathrm{~g}^{-1} \mathrm{~h}^{-1}\right)$ & $9.26(0.36)$ & $3.82(0.52)$ & $6.98(0.93)$ & $2.66(0.88)$ & $0.47(0.07)$ & $4.40(0.76)$ \\
\hline
\end{tabular}

tial addition of dimethyl sulfoxide (DMSO) and methanol $(\mathrm{MeOH})$ and quantified spectrophotometrically as described previously (Kübler \& Davison 1993).

Statistical analyses. All within-species comparisons were made using the Mann-Whitney $U$-test for comparing 2 means. Unless otherwise noted, 'significant' implies $\mathrm{p} \leq 0.05$.

\section{RESULTS}

Growth rates (biomass specific) were significantly reduced in Palmaria palmata $(\mathrm{p}=0.05)$ and Laurencia pinnatifida $(\mathrm{p}=0.05)$ when grown at 25 relative to $75 \mu \mathrm{mol}$ photons $\mathrm{m}^{-2} \mathrm{~s}^{-1}$, while the growth rate of Lomentaria articulata was not significantly affected by PFD over this range (Table 1). This suggests that the growth rate of $L$. articulata is limited by some other factor even at the low PFD used here. The biomass produced by $P$. palmata and $L$. pinnatifida grown at

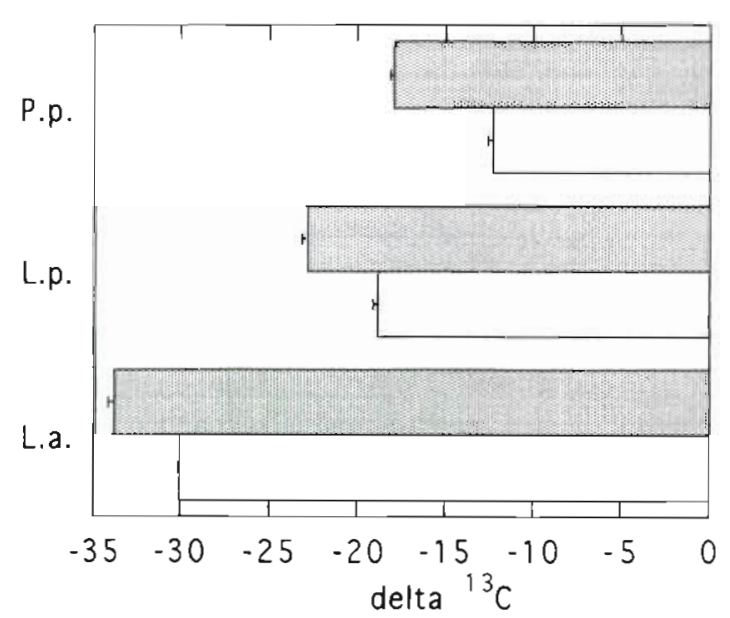

Fig. 1. $\delta^{13} \mathrm{C}$ values for organic carbon of Palmaria palmata (P.p.), Laurencia pinnatifida (L.p.) and Lomentaria articulata (L.a.) grown under PFD of $25 \mu \mathrm{mol}$ photons $\mathrm{m}^{-2} \mathrm{~s}^{-1}$ (shaded bars) or $75 \mu \mathrm{mol}$ photons $\mathrm{m}^{-2} \mathrm{~s}^{-1}$ (open bars) ( $\mathrm{n}=5$ to 10 ). Error bars $=1 \mathrm{SE}$
$75 \mu \mathrm{mol}$ photons $\mathrm{m}^{-2} \mathrm{~s}^{-1}$ had a significantly higher dry: wet mass ratio than that grown at $25 \mu \mathrm{mol}$ photons $\mathrm{m}^{-2} \mathrm{~s}^{-1}(\mathrm{p}=0.05, \mathrm{p} \leq 0.002$ for $P$. palmata and $L$. pinnatifida respectively).

$\delta^{13} \mathrm{C}$ values of high- and low-PFD-grown plants are given in Fig. 1. All species exhibited increased fractionation of stable carbon isotopes at low PFD. The increase was greatest in Palmaria palmata $(30.1 \%$ or $5.6 \%, \mathrm{p} \leq 0.001)$, intermediate in Laurencia pinnatifida $(17.9 \%$ or $4.1 \%$, p < 0.002 ) and least in Lomentaria articulata $(11.5 \%$ or $3.9 \%, p \leq 0.001)$. The stable carbon isotope ratios of the source DIC pool in the media were not found to differ at the 2 light levels (Kübler unpubl.).

The mean initial slopes of DIC uptake curves are shown in Fig. 2. The initial slope was significantly greater in high-relative to low-PFD-grown Palmaria palmata $(\mathrm{p}<0.001)$ and arguably greater in highrelative to low-PFD-grown Laurencia pinnatifida ( $\mathrm{p} \leq$ $0.10)$. The initial slope of carbon uptake in Lomentaria

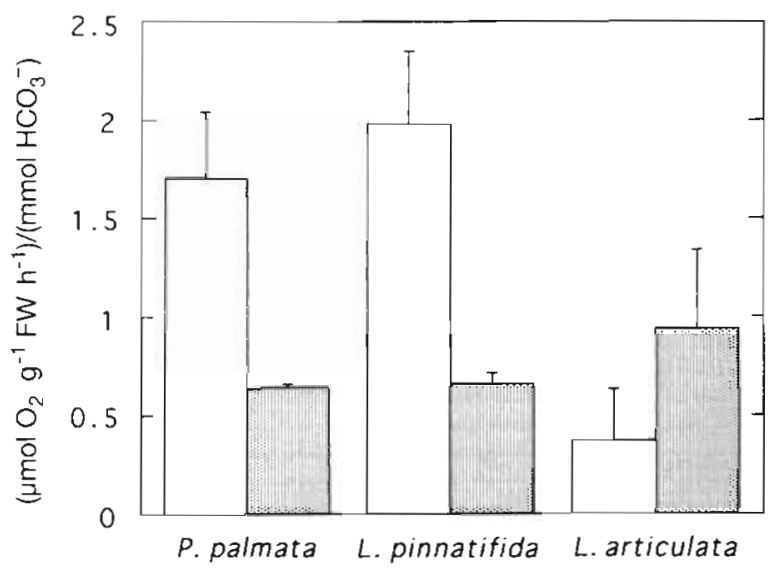

Fig. 2. Palmaria palmata, Laurencia pinnatifida and Lomentaria articulata. Initial slopes of the response of photosynthesis to DIC concentration for seaweeds grown under PFD of $25 \mu \mathrm{mol}$ photons $\mathrm{m}^{-2} \mathrm{~s}^{-1}$ (shaded bars) or $75 \mu \mathrm{mol}$ photons $m^{-2} s^{-1}$ (open bars) $(n=3)$. Error bars $=1 \mathrm{SE}$ 


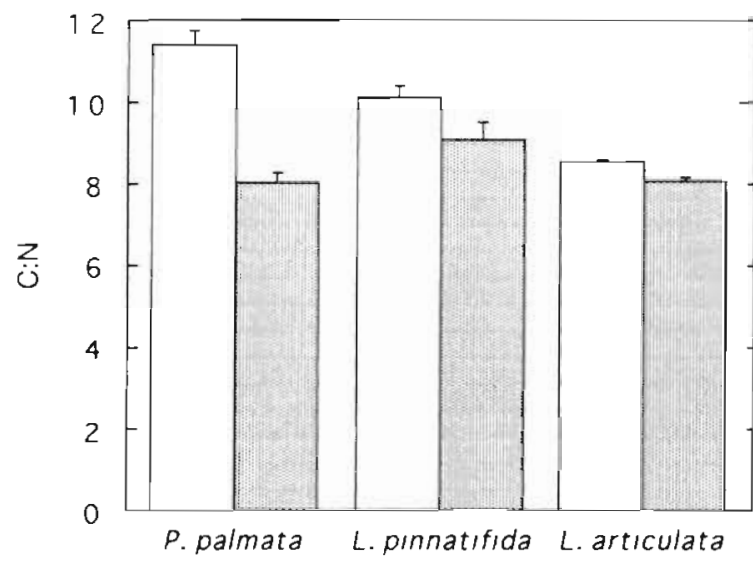

Fig. 3 Palmana palmata. Laurencia pinnatıfida and Lomentana articulata $\mathrm{C}: \mathrm{N}$ ratios for seaweeds grown under PFD of $25 \mu \mathrm{mol}$ photons $\mathrm{m}^{-2} \mathrm{~s}^{-1}$ (shaded bars) or $75 \mu \mathrm{mol}$ photons $\mathrm{m}^{-2} \mathrm{~s}^{-1}$ (open bars) $(\mathrm{n}=10)$. Error bars $=1 \mathrm{SE}$

articulata was unaffected by growth light level and was comparable to those of low-PFD-grown $P$. palmata and $L$. pinnatifida. $P_{\max }$ values of $P$. palmata and $L$. pinnatifida (Table 1) were greater for plants grown at high PFD relative to those grown at low PFD ( $p \leq 0.05$ in both cases). $P_{\max }$ of $L$. articulata grown at high PFD was significantly lower than that of low-PFD-grown plants ( $p \leq 0.05$ ), suggesting photoinhibition and cumulative damage to the photosynthetic apparatus due to carbon limitation at high PFD.

The chlorophyll a concentration on a fresh biomass basis was greater in Palmaria palmata and Lomentana articulata grown at low relative to high PFD $(\mathrm{p}<0.005$ for $P$. palmata; $p \leq 0.05$ for $L$. articulata) but was not significantly different for Laurencia pinnatifida at the 2 PFDs ( $\mathrm{p} \geq 0.05$ ) (Table 1 ).

The C:N ratio (on a mass basis) of Palmaria palmata was $11.40(\mathrm{SE}=0.35)$ when grown at $75 \pm 5 \mu \mathrm{mol}$ photons $\mathrm{m}^{-2} \mathrm{~s}^{-1}$ and $8.04(\mathrm{SE}=0.24)$ when grown at $25 \pm$ $5 \mu \mathrm{mol}$ photons $\mathrm{m}^{-2} \mathrm{~s}^{-1}(\mathrm{p} \leq 0.001$; Fig 3$)$. Similarly, Laurencia pinnatifida had $\mathrm{C}: \mathrm{N}$ ratios of 10.11 (SE =

Table 2. Palmana palmata, Laurencia pinnatifida and Lomentana artuculata Carbon fixation rate per unit tissue $\mathrm{N}$ of cultured and freshly collected seaweed. Values (mean and SE) for cultured plants grown at $25 \mu \mathrm{mol}$ photons $\mathrm{m}^{2} \mathrm{~s}^{-1}$ (low PFD) or $75 \mu \mathrm{mol}$ photons $\mathrm{m}^{-2} \mathrm{~s}^{-1}$ (high PFD) were calculated from $P_{\text {max }}(n=3)$ and nitrogen content $(n=10)$; values for freshly collected plants from the same location were taken from Johnston et al. (1992)

\begin{tabular}{|lccc|}
\hline & \multicolumn{3}{c}{ Carbon tixation rate $\left(\mu \mathrm{mol} \mathrm{O}_{2} \mathrm{mmol}^{-1} \mathrm{~N} \mathrm{~h}^{-1}\right)$} \\
& P. palmata & L. pinnatıfida & $L$ articulata \\
\hline Cultured, high PFD & $850(116)$ & $1050(204)$ & $9.58(154)$ \\
Cultured, low PFD & $23.16(090)$ & $2111(2.83)$ & $3.34(1.78)$ \\
Freshly collected & 16.81 & 9.22 & 14.55 \\
\hline
\end{tabular}

$0.29)$ and 9.08 ( $\mathrm{SE}=0.43)$ when grown at the high and low PFD, respectuvely $(p=0.05)$. The $\mathrm{C}: \mathrm{N}$ ratio of Lomentaria articulata was not significantly different at the 2 light levels (Fig. 3) and was comparable to that of P. palmata grown at low PFD (8.31, SE = 0.08). Light limitation of the growth of $P$. palmata and $L$. pinnatifida at PFD $=25 \pm 5 \mu \mathrm{mol}$ photons $\mathrm{m}^{-2} \mathrm{~s}^{-1}$ was associated with a decrease in the \% of dry biomass composed of carbon (from $34.7 \%$ to $30.6 \%$ for P. palmata, $\mathrm{p}=0.002$; from $32.4 \%$ to $30.1 \%$ for $L$. pinnatifida, $\mathrm{p}=0.01$ ). The $\%$ carbon of $L$. articulata was not different $(30.0 \%)$ at the 2 growth PFDs (Table 1) and was similar to that of the other species at $25 \pm 5 \mu \mathrm{mol}$ photons $\mathrm{m}^{-2} \mathrm{~s}^{-1}$. All 3 species showed some indication of photoacclimation as significant increases in \% nitrogen (Table 1 ) at the lower PFD. These data were suggestive of carbon limitation in high- and low-PFD-grown L. articulata and low-PFD-grown $P$. palmata and $L$. pinnatifida.

Carbon fixation rates per unit tissue nitrogen calculated for Palmaria palmata and Laurencia pinnatifida were significantly greater for high- than for low-PFDgrown plants ( $p \leq 0.05$ in both cases; Table 2). Lomentaria articulata fixed carbon faster per unit tissue $\mathrm{N}$ when grown at low PFD $(p \leq 0.05)$.

\section{DISCUSSION}

The light level at which plants were grown in the laboratory had significant effects on the $\delta^{13} \mathrm{C}$ values of the organic matter and carbon use characteristics of all 3 species (Figs. $1 \& 2$ ). Growth at 25 relative to $75 \mu \mathrm{mol}$ photons $\mathrm{m}^{-2} \mathrm{~s}^{-1}$ had contrasting effects on the carbon use characteristics of species which were previously shown to be able to use $\mathrm{HCO}_{3}{ }^{-}$for photosynthesis ( $\mathrm{Pal}$ maria palmata and Laurencia pinnatifida) and the one which was not (Lomentaria articulata) (Johnston et al. 1992). Recent analysis of a large number of macroalgae (including those used here) has shown a clear connection between $\delta^{13} \mathrm{C}$ values and $\mathrm{pH}$ compensation points (Maberly 1990, Maberly et al. 1992). More negative values of $\delta^{13} \mathrm{C}$ in plants grown at low PFD could result from several factors including lower photosynthetic rates and therefore a relative decrease in photosynthetic limitation due to DIC supply, and/or decreased usage of the $\mathrm{HCO}_{3}{ }^{-}$pool. The latter of these possibilities would also be associated with a decrease in the $\mathrm{pH}$ compensation point. We hypothesize that the decrease of $\delta^{13} \mathrm{C}$ of $P$. palmata and L. pinnatifida grown at low PFD was due to a change in the characteristics of inorganic carbon uptake, such that a smaller proportion of the carbon fixed during growth 
was actively taken up from the $\mathrm{HCO}_{3}^{-}$pool. This hypothesis was supported by the fact that the initial slope of the DIC uptake curves was significantly greater in high-PFD-grown P. palmata ( $\mathrm{p} \leq 0.001$ ), and marginally greater in high-PFD-grown $L$. pinnatifida $(p \leq 0.10)$. The initial slope of the DIC uptake curve for $L$. articulata was not significantly affected by growth PFD (Fig. 2) which is consistant with this species' being dependent on diffusive uptake of DIC at both PFDs.

There are several examples of decreasing $\delta^{13} \mathrm{C}$ values with increasing depth for both seagrasses and macroalgae (Wefer \& Killingley 1986, Cooper \& McRoy 1988, Cooper \& DeNiro 1989, Durako \& Hall 1992). This pattern is generally attributed to increasing light limitation and decreasing photosynthetic rate at depth. However, controlled experiments in which light level is the only manipulated variable are few and there are numerous other factors which would also correlate with depth including temperature, duration of exposure to air, and flow rates. An exception is found in the work of Wienke \& Fischer (1990), who identified trends of decreasing (more negative) $\delta^{13} \mathrm{C}$ with decreasing growth rate and light limitation in 8 of 12 polar or coldtemperate macroalgal species. The range of light effects, from no response to a net difference in $\delta^{13} \mathrm{C}$ of $\mathrm{ca}+20 \%$ in a period of $5 \mathrm{wk}$ (for Desmarestia antarctica; Wienke \& Fischer 1990), illustrates the huge variability in the means of carbon acquisition, and its potential for acclimation in seaweeds. The implications of decreased photosynthetic rate for carbon isotope fractionation in aquatic plants are discussed in Raven (1992). In this case, we demonstrated that a decrease in growth light level resulted in a small decrease in $\delta^{13} \mathrm{C}$ values in diffusion-limited plants (Lomentaria articulata; Fig. 1) but a large difference in plants which facultatively operate a CCM (Laurencia pinnatifida and Palmaria palmata; Fig. 1). Raven et al. (1993) proposed the poleward trend of decreasing carbon fixation rates as a potential explanation for the trend of more negative $\delta^{13} \mathrm{C}$ values in plants at higher latitudes. The relative repression of CCMs at low light level in high latitudes would also contribute to this trend. This possibility could be tested by comparing the delta values of perennials to those of summer annuals which would only be exposed to high light levels and have fully induced CCMs.

Results for Lomentaria articulata were quite different from those that would be predicted by a direct relationship between light level and inorganic carbon demand. L. articulata grown at low PFD had more negative $\delta^{13} \mathrm{C}$ than plants grown at high PFD, but this decrease was associated with greater rates of net photosynthesis and growth (Table 1). However, it seems likely that the high-PFD-grown $L$. articulata were experiencing photoinhibition and subsequent damage.
If this were the case, it is possible that the absolute rate of carbon fixation was greater at the higher light level but was accompanied by a greater requirement for maintenance respiration and, thereby, lower net photosynthetic and growth rates. It should be noted that the high PFD used in the laboratory $(75 \pm 5 \mu \mathrm{mol}$ photons $\mathrm{m}^{-2} \mathrm{~s}^{-1}$ ), although growth-saturating for many marine macroalgae, is only $-5 \%$ of full sunlight and even shaded microhabitats in the intertidal are likely to experience PFDs $>75 \mu \mathrm{mol}$ photons $\mathrm{m}^{-2} \mathrm{~s}^{-1}$ at low tide. Partial photoinhibition may serve as a photoprotective mechanism, allowing $L$. articulata to survive and grow at light levels in excess of those it can use for carbon fixation. A mechanism by which photoinhibited PSII reaction centers serve to nonphotochemically dissipate excess excitation energy has been described for the terrestrial shade plant Tradescantia albiflora (Adamson et al. 1991, Öquist et al. 1992a, b) and may also operate in L. articulata.

Based on the response of these species to growth light level in the laboratory, it is possible to speculate about the light environments the freshly collected plants used by Johnston et al. (1992) and Maberly et al. (1992) may have experienced. Comparing the $\delta^{13} \mathrm{C}$ values for the organic carbon of lab-grown (Fig. 1) and freshly collected plants (Maberly et al. 1992) we see that for Lomentaria articulata and Laurencia pinnatifida, high-PFD-grown lab plants $\left(\delta^{13} \mathrm{C}=-30.0 \%\right.$ and $-18.83 \%$ respectively) were similar to the freshly collected plants $(-30.0 \%$ and $-17.3 \%$ respectively) while low-PFD-grown plants were more negative $(-33.9 \%$ and $-22.9 \%$ respectively). In the case of Palmaria palmata, the high-PFD-grown plants $\left(\delta^{13} \mathrm{C}=-12.3 \%\right)$ were similar to the 'drift' population of Maberly et al. (1992) (-14.5\%) while the low-PFD-grown plants were more like those of the attached population of Maberly et al. (1992) ( $\delta^{13} \mathrm{C}=-17.9$ and $-18.5 \%$ respectively). Such comparisons suggest that $L$. articulata and $L$. pinnatifida were not extremely light limited in the field and that $P$. palmata collected as drift were exposed to higher PFD than the attached population. However, our initial attempts to correlate the degree of natural shading in an attached population of $P$. palmata with the $\delta^{13} \mathrm{C}$ values of the organic carbon have been unsuccessful (Kübler unpubl.).

Taken together, the data for $\delta^{13} \mathrm{C}$ of organic carbon and the initial slopes of inorganic carbon uptake curves suggest the presence of an inducible CCM in Palmaria palmata and potentially in Laurencia pinnatifida but not in Lomentaria articulata. This is consistent with the hypothesis proposed by Johnston et al. (1992) that plants without an evident CCM in field collections are restricted to shaded environments because they are limited by the rate of diffusive uptake of $\mathrm{CO}_{2}$. It does not appear that $L$. articulata can be induced to 
express a CCM if grown at higher light levels. In this respect it is interesting to note that in fresh water the plants found at the depth limit, which are probably light-limited, are usually facultative or obligate nonusers of $\mathrm{HCO}_{3}^{-}$(Boston et al. 1989).

The fact that the ability to use $\mathrm{HCO}_{3}{ }^{-}$for photosynthesis appears to be facultative suggests that it is energetically expensive or, assuming optimal functioning, that the advantage of being able to use $\mathrm{HCO}_{3}{ }^{-}$at any time carbon becomes limiting is outweighed by the cost of maintaining the ability. It is not clear from the results given here whether the derepression of $\mathrm{HCO}_{3}^{-}$ use at low light is cued by the alleviation of carbon limitation at low light or by the diversion of energetic resources to photoacclimation. The chlorophyll a content of Palmaria palmata was significantly greater for plants grown at low relative to high PFD (Table 1), indicating photoacclimation of this species. In contrast, the chlorophyll a content of Laurencia pinnatifida was not significantly affected by the growth light level. The carbon fixation rates per unit tissue $N$ of $P$. palmata and $L$. pinnatifida were significantly lower when grown at low PFD relative to high PFD (Table 2). Comparing these values to those for freshly collected plants which were able to use $\mathrm{HCO}_{3}{ }^{-}$(Johnston et al. 1992), the value in high-PFD-grown $L$. pinnatifida was greater than that of the freshly collected $L$. pinnatifida. In contrast, the value in the freshly collected $P$. palmata was intermediate between the high- and low-PFD-grown $P$. palmata. Taken together, these results indicate that $P$. palmata and $L$. pinnatifida have a greater nitrogen requirement at lower $\mathrm{PFD}$, which is consistent with photoacclimation increasing light harvesting, and that growth at the high PFD in the laboratory resulted in a lower $N$ cost of growth (more effective use of $N$ ) than occurred in the field population. The lower $N$ cost for growth of Lomentaria articulata at high PFD is consistent with its low photosynthetic rate and probable photoinhibition.

Summarizing, we have illustrated the repression of an inorganic carbon uptake mechanism in 2 species of red macroalgae by growth at low PFD. Palmaria palmata and Laurencia pinnatifida exhibited more efficient uptake of limiting concentrations of inorganic carbon, less negative $\delta^{13} \mathrm{C}$ values and greater nitrogen use efficiency when grown at a growth-saturating PFD compared to plants grown at a limiting PFD. In contrast, Lomentaria articulata, which is unable to utilize the bicarbonate pool for photosynthesis, did not gain any advantage in terms of photosynthetic or growth rate when grown at increased PFD.

Acknowledgements. This work was supported by the Natural Environment Research Council (UK) under Grant Number GR3/8463. We thank Dr A. M. Johnston for many useful discussions and technical assistance. Dr C. M. Scrimgeour and the staff of the Department of Anatomy and Physiology, University of Dundee, provided invaluable support for the mass spectrometric measurements.

\section{LITERATURE CITED}

Adamson, H. Y., Chow, W. S., Anderson, J M., Vesk, M., Sutherland, M. W. (1991). Photosynthetic acclimation of Tradescantia albiflora to growth irradiance: morphological, ultrastructural and growth responses. Physiol. Plant. 82: $353-359$

Beardall, J. (1991). Effects of photon flux density on the ' $\mathrm{CO}_{2}$ concentrating mechanism' of the cyanobacterium Anabaena variabilis. J. Plankton. Res. 13 (suppl.): 133-141

Beer, S., Israel, A. (1990). Photosynthesis of Ulva fasciata. IV. $\mathrm{pH}$, carbonic anhydrase and inorganic carbon conversions in the unstirred layer. Plant Cell Environ. 13: 555-560

Bidwell, R. G., MacLachlan, J. (1985). Carbon nutrition of seaweeds: photosynthesis, photosynthesis and respiration. J. exp. mar. Biol. Ecol. 86: 15-46

Boston, H. L., Adams, M. S., Madsen, J. D. (1989). Photosynthetic strategies and productivity in aquatic systems. Aquat. Bot. 34: 27-57

Cook, C. M., Colman, B. (1987). Some characteristics of photosynthetic carbon uptake of marine macrophytic red algae. Plant Cell Environ. 10: 275-278

Cook, C. M., Lanaras, T., Roubelakis-Angelakis, K. A. (1988). Bicarbonate transport and alkalization of the medium by four species of Rhodophyta. J. exp. Bot. 39: 1185-1198

Cooper, L. W., DeNiro, M. J. (1989). Stable carbon isotope variability in the seagrass Posidonia oceanica: evidence for light intensity effects. Mar. Ecol. Prog. Ser. 50: 225-229

Cooper, L. W., McRoy, C. P. (1988). Stable carbon isotope variations along intertidal gradients. Oecologia 77: 238-241

Durako, M. J., Hall, M. O. (1992). Effects of light on the stable carbon isotope composition of the seagrass Thalassia testudinum. Mar. Ecol. Prog. Ser. 86: 99-101

Johnston, A. M., Maberly, S. C., Raven, J. A. (1992). The acquisition of inorganic carbon by four red macroalgae from different habitats. Oecologia 92: 317-326

Kübler, J. E., Davison, I. R. (1993). High-temperature tolerance of photosynthesis in the red alga Chondrus crispus. Mar. Biol. 117: 327-335

Levavasseur, G., Edwards, G. E., Osmond, C. B., Ramus, J. (1991). Inorganic carbon limitation of photosynthesis in Ulva rotundata. J. Phycol. 27: 667-672

Maberly, S. C. (1990). Exogenous sources of inorganic carbon for photosynthesis by marine macroalgae. J. Phycol. 26: $439-449$

Maberly, S. C., Raven, J. A., Johnston, A. M. (1992). Discrimination between ${ }^{13} \mathrm{C}$ and ${ }^{12} \mathrm{C}$ by marine plants. Oecologia 91: $481-492$

Mook, W. G., Bommerson, J. C., Staverman, W. H. (1974). Carbon isotope fractionation with diffusion of carbon dioxide and gaseous carbon dioxide. Earth planet. Sci. Lett. 22: $169-176$

O'Leary, M. H. (1992). Physical and chemical basis of carbon isotope fractionation in plants. Plant Cell Environ. 15: $1099-1104$

Öquist, G., Anderson, J. M., McCaffery, S., Chow, W. S. (1992a). Mechanistic differences in photoinhibition of sun and shade plants. Planta 188: 422-431

Öquist, G., Chow, W. S., Anderson, J. M. (1992b). Photoinhibition of photosynthesis represents a mechanism for the long-term regulation of photosystem II. Planta 186: $450-460$ 
Provasoli, L. (1968). Media and prospects for the cultivation of marine algae. In: Watanabe, A., Hattori, A. (eds.) Cultures and collection of algae. Japanese Society of Plant Physiology, Hokane, p. 63-75

Ramazanov, Z., Mason, C. B., Geraghty, A. M., Spalding, M. H., Moroney, J. V. (1993). The low $\mathrm{CO}_{2}$-inducible $36 \mathrm{kD}$ protein is localized to the chloroplast envelope of Chlamydomonas reinhardtii. Plant Physiol. 101: 1195-1199

Raven, J. A. (1992). Present and potential uses of the natural abundance of stable isotopes in plant science, with illustrations from the marine environment. Plant Cell Environ. 15: 1083-1091

Raven, J. A., Johnston, A. M., Turpin, D. H. (1993). Influence of changes in $\mathrm{CO}_{2}$ concentration and temperature on marine phytoplankton ${ }^{13} \mathrm{C} /{ }^{12} \mathrm{C}$ ratios: an analysis of possible mechanisms. Global planet. Change 8: 1-12

Raven, J. A., Lucas, W. J. (1985). The energetics of carbon acquisition. In: Lucas, W. J., Berry, J. A. (eds.) Inorganic carbon uptake by aquatic photosynthetic organisms. The American Society of Plant Physiologists, Rockville, MD,

This article was submitted to the editor p. 305-324

Rotatore, C., Lew, R. R., Colman, B. (1992). Active uptake of $\mathrm{CO}_{2}$ during photosynthesis in the green alga Eremosphaera viridis is mediated by a $\mathrm{CO}_{2}$-ATPase. Planta 188 : $539-545$

Smith, R. G., Bidwell, R. G. S. (1989). Inorganic carbon uptake by photosynthetically active protoplasts of the red macroalga Chondrus crispus. Mar. Biol. 102: 1-4

Surif, M. B., Raven, J. A. (1990). Photosynthetic gas exchange under emersed conditions in eulittoral and normally submersed members of the Fucales and Laminariales: interpretation in relation to $C$ isotope ratio and $N$ and water use efficiency. Oecologia 82: 68-80

Wefer, G., Killingley, J. S. (1986). Carbon isotopes in organic matter from a benthic alga Halimeda incrassata (Bermuda): effects of light intensity. Chem. Geol. (Isotope Geosciences Section) 59: 321-326

Wiencke, C., Fischer, G. (1990). Growth and stable carbon isotope composition of cold-water macroalgae in relation to light and temperature. Mar. Ecol. Prog. Ser. 65: 283-292

Manuscript first received: January 25, 1994

Revised version accepted: April 11, 1994 